\section{BMJ Open Ophthalmology}

\title{
Differences in SARS-CoV-2 recommendations from major ophthalmology societies worldwide
}

\author{
Anne X Nguyen (D) , ${ }^{1}$ Kalla A Gervasio (D) , ${ }^{2}$ Albert Y Wu (D) ${ }^{3}$
}

\section{To cite: Nguyen $A X$, Gervasio KA, Wu AY. Differences in SARS-CoV-2 recommendations from major ophthalmology societies worldwide. BMJ Open Ophthalmology 2020;5:e000525. doi:10.1136/ bmjophth-2020-000525}

- Additional material is published online only. To view please visit the journal online (http://dx.doi.org/10.1136/ bmjophth-2020-000525).

Received 21 May 2020 Revised 25 June 2020 Accepted 29 June 2020
A) Check for updates

(C) Author(s) (or their employer(s)) 2020. Re-use permitted under CC BY-NC. No commercial re-use. See rights and permissions. Published by BMJ.

${ }^{1}$ Faculty of Medicine, McGill University, Montreal, Quebec, Canada

2Department of Ophthalmology, Wills Eye Hospital, Philadelphia, Pennsylvania, USA

${ }^{3}$ Department of Ophthalmology, Stanford University School of Medicine, Stanford, California, USA

Correspondence to Albert YWu; awu1@stanford. edu

\section{ABSTRACT}

Objective Since the WHO declared the COVID-19

outbreak as a public health emergency, medical societies around the world published COVID-19 recommendations to physicians to ensure patient care and physician safety. During this pandemic, ophthalmologists around the world adapted their clinical and surgical practice following such guidelines. This original research examines all publicly available COVID-19 recommendations from twelve major ophthalmology societies around the world.

Methods and analysis Twelve ophthalmology societies recognised by the International Council of Ophthalmology were included in this study. One society per each WHO region was included: the society selected was the one who had the highest number of national COVID-19 confirmed cases on 11 May 2020. In addition to these countries, the major ophthalmology society in each G7 country was included.

Results Ten out of 12 major international ophthalmology societies from countries covering all six WHO regions have given recommendations regarding urgent patient care, social distancing, telemedicine and personal protective equipment when caring for ophthalmic patients during the COVID-19 pandemic. While all guidelines emphasise the importance of postponing non-urgent care and taking necessary safety measures, specific recommendations differ between countries.

Conclusions As there is no clear consensus on ophthalmology guidelines across countries, this paper highlights the differences in international ophthalmic care recommendations during the COVID-19 pandemic. Knowledge of the differences in ophthalmic management plans will allow ophthalmologists and all eye care providers to consider the variety of international approaches and apply best practices following evidencebased recommendations during pandemics.

\section{INTRODUCTION}

As of 11 May 2020, there have been more than 4 million confirmed cases of the coronavirus disease 2019, known as COVID-19 or severe acute respiratory syndrome coronavirus (SARS-CoV-2), around the world. ${ }^{1}$ Since the emergence of this novel severe acute respiratory virus in November 2019, the number of patients with COVID-19 and deaths have been escalating, which prompted the WHO to declare the outbreak as a Public

\section{Key messages}

What is already known about this subject?

To date, no study has examined COVID-19 recommendations from ophthalmology societies worldwide.

\section{What are the new findings?}

- All major ophthalmology societies from the G7 countries in addition to Sociedad Española de Oftalmología, All India Ophthalmological Society and Ophthalmological Society of South Africa have provided valuable information regarding urgent patient care, social distancing, telemedicine and personal protective equipment for members on their websites.

How might these results change the focus of research or clinical practice?

Knowledge of the differences in ophthalmic management plans will allow ophthalmologists and all eye care providers to consider the variety of international approaches and apply best practices following evidence-based recommendations during pandemics.

Health Emergency of International Concern (30 January 2020). ${ }^{2}$

Current evidence indicates that COVID-19 is commonly spread by droplet transmission and by asymptomatic carriers. Initial findings suggest that the virus may propagate via airborne transmission (eg, aerosol contact with conjunctiva and respiratory mucosa), especially in high-risk procedures like endotracheal intubation. ${ }^{3}$ While conjunctivitis has less frequently been reported as a coronavirus symptom, it is still unclear if the virus can be transmitted through tears. ${ }^{45}$

Physicians are at great risk of contracting the virus due to their close proximity with patients. The 230,000 ophthalmologists around the world are particularly susceptible, as they routinely perform surgeries and slitlamp examinations at less than $20 \mathrm{~cm}$ from patients. In order to ensure physician safety and patient care, medical societies have issued 
recommendations about clinical and hospital-based practices to adopt during COVID-19.

The purpose of this article is to assess the major international ophthalmology societies' recommendations regarding patient care, social distancing, telemedicine and the use of personal protective equipment (PPE) when caring for ophthalmic patients during the COVID-19 pandemic. The goal is to assist ophthalmologists and all eye care providers in understanding the diversity in international guidelines available and to apply best practices based on these recommendations.

\section{METHODS}

This original research examines all publicly available COVID-19 recommendations from 12 major ophthalmology societies around the world. Twelve ophthalmology societies, covering all six WHO regions (African region, region of the Americas, Southeast Asia region, European region, Eastern Mediterranean region and Western Pacific region), were included in this paper. We selected the country with the highest number of confirmed COVID-19 cases in each region on 11 May 2020: USA, Spain, India, South Africa, Iran and China. ${ }^{1}$ In addition to those countries, all G7 countries were examined: UK, USA, Canada, France, Germany, Italy and Japan. Developed in 1976, the G7 countries refer to a group of seven industrialised nations who meet annually to discuss a variety of global issues (ie, economy, environment and security) (online supplementary table 1).

The leading ophthalmology society in each of the 12 countries was selected from the International Council of Ophthalmology repertoire, which contains 179 members. These ophthalmology societies are the most popular national general ophthalmology societies in their respective countries, as per their number of members (table 1). The publicly available data displayed on these societies' official websites were extracted, translated into English when applicable (Sociedad Española de Oftalmología (SEO), Société Française d'Ophthalmologie (SFO), Deutsche Ophthalmologische Gesselschaft (DOG), Società Oftalmologica Italiana (SOI), Japanese Ophthalmological Society (JOS), Iranian Society of Ophthalmology (IRSO) and Chinese Ophthalmological Society (CHOS)) and analysed in this paper.

It is important to note that this paper reflects the societies' respective status as of 11 May 2020 and that these guidelines are subject to change.

\section{Patient involvement}

Patients were not directly involved in the design of this study.

\section{RESULTS}

\section{Overview of ophthalmology societies}

The 12 ophthalmology societies examined include the following: the Royal College of Ophthalmologists (RCOphth) in the UK, ${ }^{6}$ the American Academy of Ophthalmology (AAO), ${ }^{7}$ the Canadian Ophthalmological
Society (COS),${ }^{8}$ SEO,${ }^{9}$ SFO, DOG, ${ }^{10}$ SOI,${ }^{11}$ JOS,${ }^{12}$ the All India Ophthalmological Society (AIOS),${ }^{13}$ the Ophthalmological Society of South Africa (OSSA), ${ }^{14} \mathrm{CHOS}^{15}$ and $\operatorname{IRSO}^{16}$ (table 1).

\section{Overview of COVID-19 information}

Eleven out of twelve societies have a website that releases information for their members and patients. CHOS does not have its own website, as the description of the society is found on the Asia-Pacific Academy of Ophthalmology web page and refers readers to the Chinese Medical Association (CMA) website. ${ }^{15}$ On the CMA's website, there are no guidelines for ophthalmologists in the context of the pandemic. Out of these 11 societies, 10 websites had information regarding the COVID-19 pandemic as there were no guidelines found on the IRSO webpage (table 1).

Ophthalmology societies have promoted their first COVID-19 guidelines from 11 February (SOI) to 28 March 2020 (AIOS) (figure 1). The actual effect of the guidelines used is variable when looking at reported laboratory-confirmed COVID-19 cases (online supplementary figure 1 ).

\section{Urgent versus non-urgent care}

Table 2 highlights examples of urgent and non-urgent procedures provided by each society.

For instance, RCOphth displays UK-based resources, like the Moorfields Eye Hospital National Health Service (NHS) Foundation Trust, and emits its own guidelines on urgent and non-urgent care. It also states that all routine ophthalmic surgeries and face-to-face outpatient must be delayed, except if patients are at elevated risk of harm. Ophthalmology accident and emergency departments must remain open with appropriate support to ensure adequate patient triage and consultations. ${ }^{17}$

AAO listed 53 suggestions of 'urgent' surgical procedures associated with indications. For example, ophthalmologists should perform brachytherapy for intraocular malignancy. ${ }^{18} \mathrm{COS}$, AIOS and JOS display this comprehensive list on their website but also published their own guidelines.

AIOS provided a list of twenty ophthalmic emergencies, which are very similar to AAO's. In addition to those emergencies, it provides a list of 11 complaints in order to rule out emergencies (ie, chemical/thermal/mechanical eye injury, acute red eye, photophobia and sudden halos/floaters/discharge/eyelid drooping). ${ }^{19}$

While referring its members to AAO's resources, JOS has its own list examples regarding urgent treatment, notably retinal detachment, ocular trauma and retinoblastoma. The list has then been updated to include more examples of urgent care (ie, paediatric glaucoma, orbital fracture and bulging cataracts). Unlike the other societies that consider common adult cataract surgery as an elective treatment, JOS mentions that delaying cataract surgeries depend on each patient's circumstances. ${ }^{12}$ 


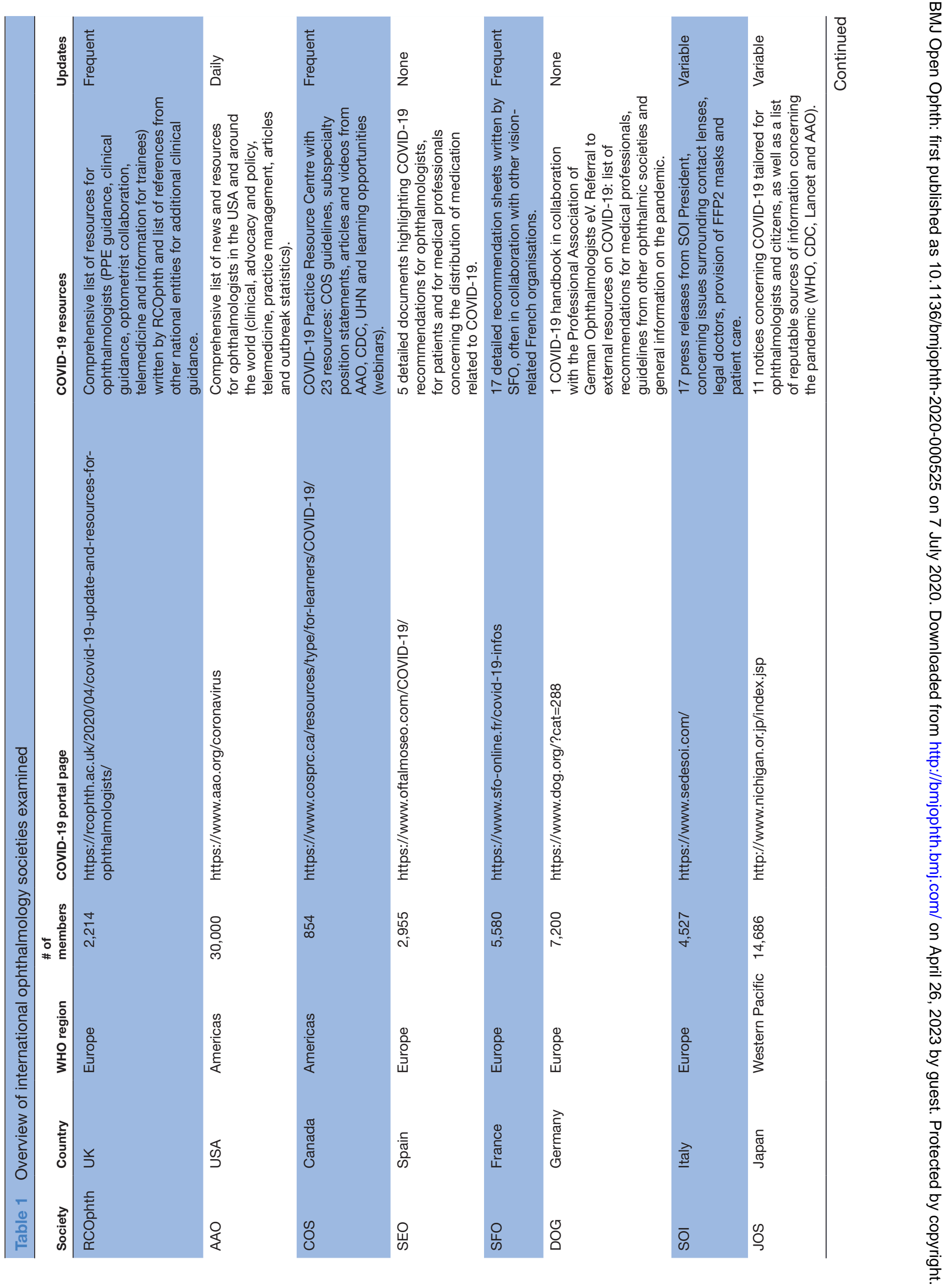




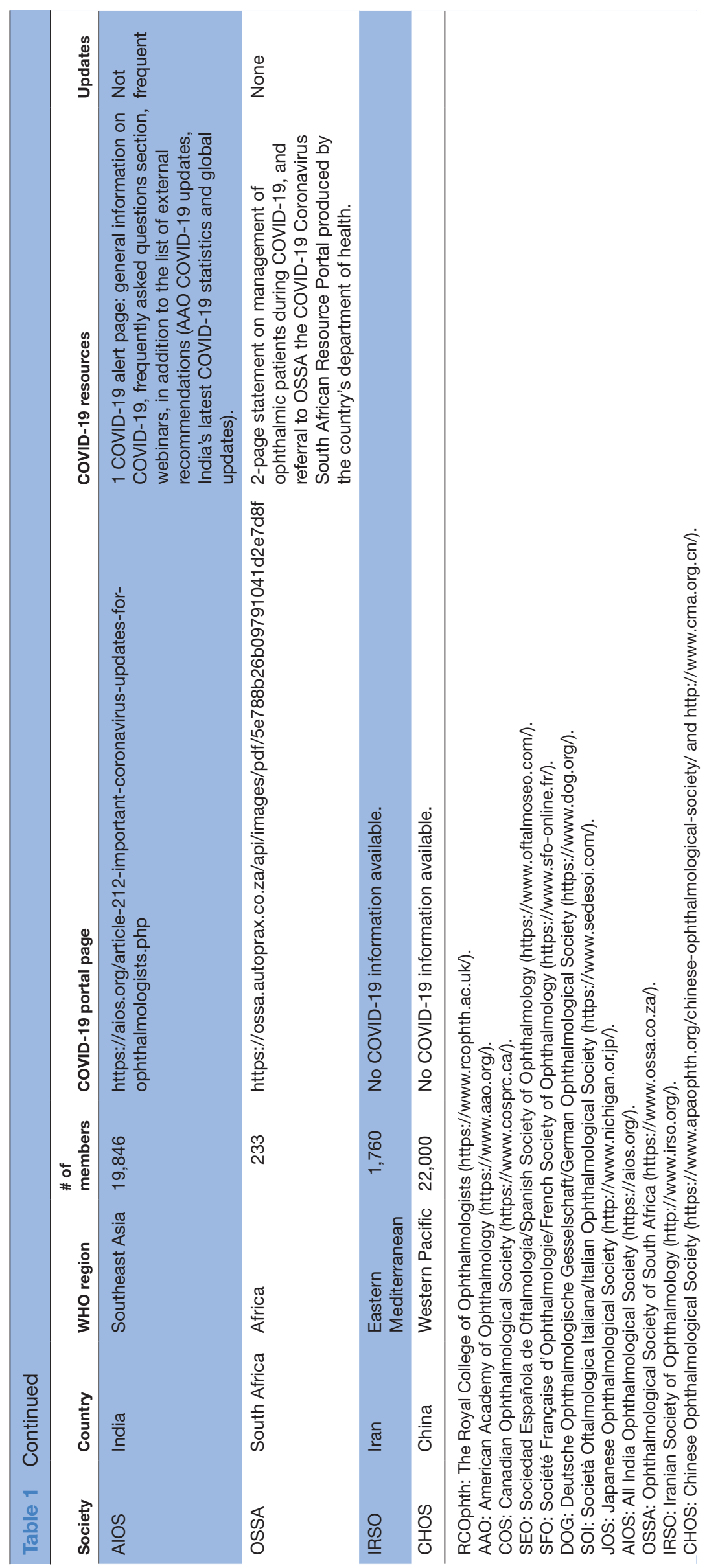

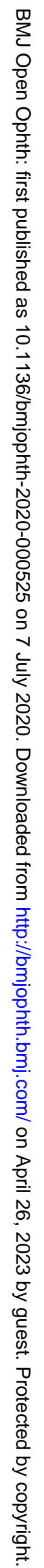



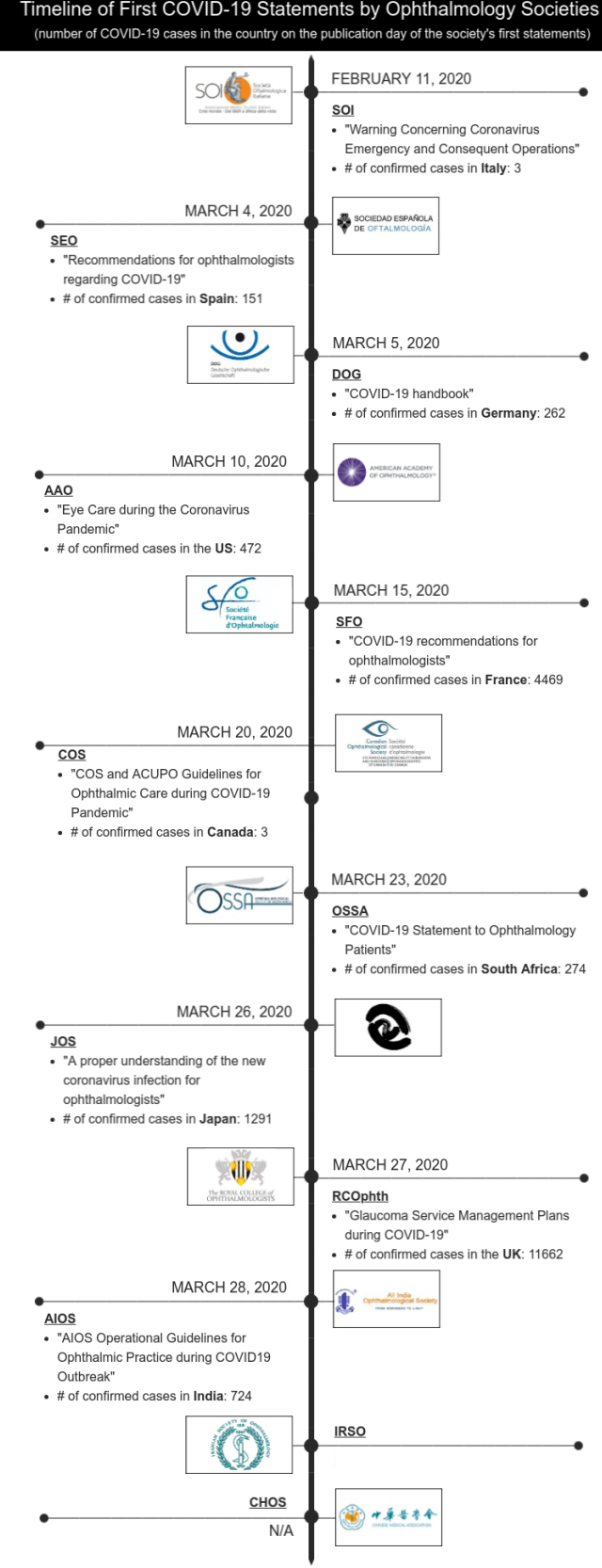

Figure 1 Timeline of the first COVID-19 recommendation published by major international ophthalmology societies and number of COVID-19 confirmed cases per country. Figure 1 uses the logos of ophthalmology societies and is illustrated by coauthor AX-LN.

In contrast to COS, AIOS and JOS, DOG did not recreate a list of suggestions and directly refers its members to existing resources, like to AAO's comprehensive recommendations. However, DOG does highlight that all elective interventions and consultations, including cataract surgery, must be avoided. ${ }^{20}$

SEO used AAO's list but translated it into Spanish and classified the different procedures into clinically relevant groups in order to create a list of urgent ophthalmic surgical procedures for its members. SEO also adapted Moorfields Eye Hospital NHS Foundation Trust, a resource displayed on the RCOphth's portal, to stratify the ophthalmological risk according to the type of pathology (eg, glaucoma, uveitis and strabismus).

Similarly to RCOphth, SFO uses national resources and writes its own recommendations in association with other French societies. SFO strongly recommended that its members limit all surgical and medical elective surgeries and provides distinctions between urgent, semiurgent and elective cases. Similarly to the previous societies, it mentions that retinal detachments that occurred within the past month and acute endophthalmitis with decreased vision were deemed emergencies. However, it gives examples of elective cases, such as macular holes and posterior intraocular lens dislocation, ${ }^{21}$ and provides distinctions between urgent and semiurgent. Semiurgent is defined as a risk of severe and permanent loss of vision without immediate surgery that is not as high as in urgent cases but management may only be delayed for a few days with very close monitoring. This includes retinal detachments of more than a month, as well as wounds of the globe with or without an intraocular foreign body, which are both deemed urgent by the AAO.

In contrast to the other societies, SOI's president used the video medium to explain differences between urgent and nonurgent care. The Italian video acts as a comprehensive 'User Manual' for medical eye care. The president highlights that the hospitals are now dedicated to the care of patients with COVID-19, but there will always be patients requiring immediate eye care (eg, patients with acute glaucoma). ${ }^{22}$

OSSA recommended that ophthalmologists cancel or postpone all non-essential surgeries and appointments but did not give examples of such non-urgent procedures. $^{23}$

\section{Shelter in place and telemedicine}

The ophthalmology societies follow their national guidelines. All nine societies, except JOS, have mentioned that patients and physicians alike should always stay at home, except if absolutely necessary. ${ }^{20}$ JOS is the only society examined who acknowledges eye surgery risks and possible disease transmission in asymptomatic people, but JOS does not insist on the importance of physicians staying at home as there is no lockdown rules in Japan.

Table 3 lists the telemedicine resources available per society. For example, RCOphth provides telehealth resources and compiled a telemedicine application list for ophthalmology consultations to its members. In its specific ophthalmic management plans, RCOphth mentions which cases can be managed virtually (eg, uveitis patients on immunosuppression) ${ }^{24}{ }^{25} \mathrm{AAO}$ also has an entire section dedicated to telemedicine resources ${ }^{26}$ : tips for success, ${ }^{27}$ guide to start, ${ }^{28}$ coding for telehealth consultations, ${ }^{29}$ teleworking considerations ${ }^{30}$ and statements from the academy and federal agencies. ${ }^{31}$ Other societies, like COS, simply recommend their members to consider virtual platforms, such as telephone and videoconferences, ${ }^{32}$ and refer them to AAO. 
Table 2 Summary of recommendations on urgent care for ophthalmologists during the COVID-19 pandemic per international ophthalmology society

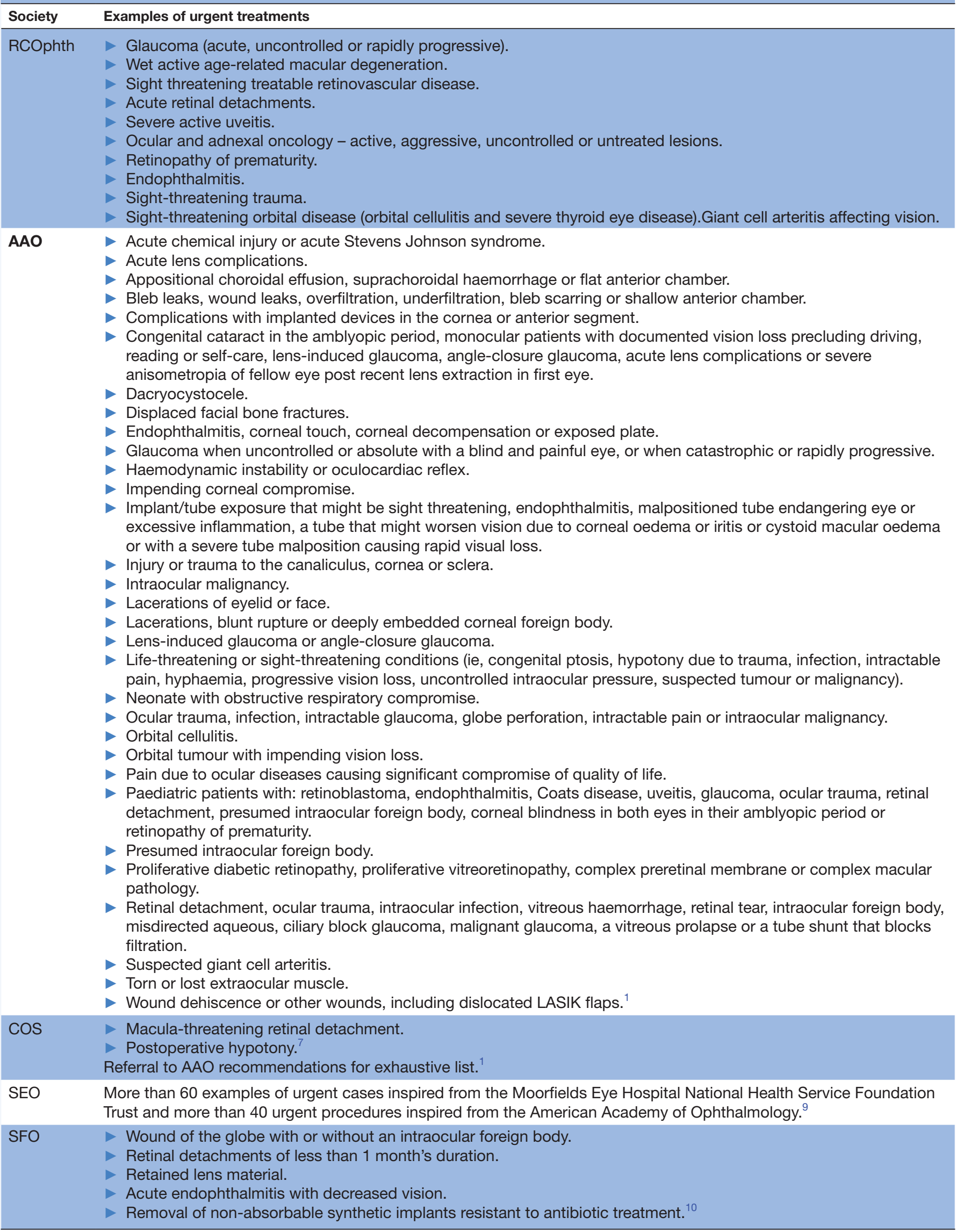




\begin{tabular}{|c|c|}
\hline Society & Examples of urgent treatments \\
\hline DOG & Referral to AAO website and other resources. ${ }^{8}$ \\
\hline SOI & Acute glaucoma patients. ${ }^{12}$ \\
\hline JOS & $\begin{array}{l}\text { Diseases leading to blindness or complications: retinal detachment, bulging cataracts and retinopathy of prematurity. } \\
\text { Malignant tumours: retinoblastoma, malignant melanoma, squamous cell carcinoma and orbital tumour. } \\
\text { Ocular trauma: corneal perforation, conjunctival laceration, ocular rupture, orbital fracture, intraocular foreign body, } \\
\text { intraocular foreign body, corneal foreign body, corneal foreign body and traumatic flap detachment after LASIK } \\
\text { surgery. } \\
\text { Infectious diseases: postoperative intraocular inflammation, eyelid abscess, lacrimal sac inflammation and intraocular } \\
\text { inflammation associated with filtration vesicle infection. } \\
\text { Glaucoma: paediatric glaucoma, rapidly progressing glaucoma and lens-derived glaucoma. } \\
\text { Other: corneal transplants, congenital cataracts requiring amblyopia treatment, traumatic cataracts, important } \\
\text { ophthalmic surgery and intravitreal injections. }{ }^{13}\end{array}$ \\
\hline AIOS & $\begin{array}{l}\text { Chemical injuries. } \\
\text { Blunt trauma or perforating injuries. } \\
\text { Open globe injuries with or without foreign body. } \\
\text { Lid trauma. } \\
\text { Angle closure glaucoma. } \\
\text { Neovascular glaucoma. } \\
\text { Elevated intraocular pressure }>38 \mathrm{~mm} \mathrm{Hg.} \\
\text { History of recent onset sudden vision loss (<2 weeks) - central retinal artery occlusion (CRAO), central retinal vein } \\
\text { occlusion (CRVO), vitreous hemorhage (VH), retinal detachment. } \\
\text { Retinal tears. } \\
\text { Endophthalmis. } \\
\text { Expulsive choroidal haemorrhage. } \\
\text { Exposed infected buckle. } \\
\text { Orbital cases with vision loss. } \\
\text { Severe inflammation - lid/orbit. } \\
\text { Tumour cases with vision loss. } \\
\text { Corneal abrasion/superficial foreign body (including contact lens lost in eye)/ulcer. } \\
\text { Postoperative follow-up. } \\
\text { Patients requiring intravitreal injections with fresh bleed or those requiring for endophthalmitis. } \\
\text { One eyed patients on anti-vascular endothelial growth factor (VEGF) with sudden loss of vision. }{ }^{14}\end{array}$ \\
\hline OSSA & No examples provided. \\
\hline IRSO & No COVID-19 information available. \\
\hline $\mathrm{CHOS}$ & No COVID-19 information available. \\
\hline
\end{tabular}

RCOphth: The Royal College of Ophthalmologists (https://www.rcophth.ac.uk/).

AAO: American Academy of Ophthalmology (https://www.aao.org/).

COS: Canadian Ophthalmological Society (https://www.cosprc.ca/).

SEO: Sociedad Española de Oftalmología/Spanish Society of Ophthalmology (https://www.oftalmoseo.com/).

SFO: Société Française d'Ophthalmologie/French Society of Ophthalmology (https://www.sfo-online.fr/).

DOG: Deutsche Ophthalmologische Gesselschaft/German Ophthalmological Society (https://www.dog.org/).

SOI: Società Oftalmologica Italiana/Italian Ophthalmological Society (https://www.sedesoi.com/).

JOS: Japanese Ophthalmological Society (http://www.nichigan.or.jp/).

AIOS: All India Ophthalmological Society (https://aios.org/).

OSSA: Ophthalmological Society of South Africa (https://www.ossa.co.za/).

IRSO: Iranian Society of Ophthalmology (http://www.irso.org/).

CHOS: Chinese Ophthalmological Society (https://www.apaophth.org/chinese-ophthalmological-society/ and http://www.cma.org.cn/).

\section{Ophthalmic management plans in the context of the} pandemic

Retina

RCOphth, AAO, COS and SFO each published guidelines for intravitreal injections and management of retinal patients. RCOphth recommends that patients with known wet age-related macular degeneration (AMD), diabetic macular oedema, branch retinal vein occlusion, central retinal vein occlusion and central serous chorioretinopathy have their appointments postponed. While panretinal photocoagulation (PRP) laser might be done with the appropriate PPE (masks, breathguard and so on), RCOphth suggests that one extensive PRP laser be done in order to delay the following PRP session. RCOphth recommends deferring pars plana vitrectomy when possible. ${ }^{25} 33$ In the USA, it is recommended that the retina clinic be restricted to indispensable visits only (ie, early postoperative visits, emergency cases and patients receiving intravitreal injection therapy). ${ }^{34} 35 \mathrm{COS}$ and SFO give specific guidelines on intravitreal injections for diabetic retinopathy. CAN-OS recommends the 'Treat and Extend' approach for neovascular AMD 
Table 3 Summary of telemedicine resources for ophthalmologists during the COVID-19 pandemic per international ophthalmology society

\begin{tabular}{|c|c|}
\hline Society & Examples of telemedicine resources \\
\hline RCOphth & $\begin{array}{l}\text { Recommended } \\
\text { Resources highlighted: } \\
\text { Telemedicine Options for Ophthalmology } \\
\text { Consultations. } \\
\text { Norfolk and Norwich Hospital (NNUH) use } \\
\text { of telemedicine during COVID-19. }\end{array}$ \\
\hline $\mathrm{AAO}$ & $\begin{array}{l}\text { Recommended } \\
\text { Resources highlighted: } \\
\text { Telehealth Resources: Tips to Help Your } \\
\text { Practice Succeed. }{ }^{2} \\
\text { - } \text { Teleophthalmology: How to Get Started. }^{3} \\
\text { Coding for Phone Calls, Internet and } \\
\text { Telehealth Consultations. }^{4} \\
\text { COVID-19 Moves Telemedicine to the } \\
\text { Forefront. }^{5} \\
\text { Academy, Federal Agencies Issue New } \\
\text { Telehealth Guidance for COVID-19. }\end{array}$ \\
\hline $\cos$ & $\begin{array}{l}\text { Recommended } \\
\text { Referral to AAO resources. }^{8}\end{array}$ \\
\hline SEO & $\begin{array}{l}\text { Telematics (voice call and video call) } \\
\text { recommended. }{ }^{9}\end{array}$ \\
\hline SFO & Telephone calls recommended. ${ }^{11}$ \\
\hline DOG & $\begin{array}{l}\text { Recommended } \\
\text { Referral to AAO resources. }^{8}\end{array}$ \\
\hline SOI & Recommended. $^{12}$ \\
\hline JOS & Not indicated. \\
\hline AIOS & $\begin{array}{l}\text { Recommended } \\
\text { Resources highlighted: } \\
\text { Live Webinar: Telemedicine in } \\
\text { Ophthalmology - Current Platforms. }{ }^{15} \\
\text { AIOS Telemedicine Practice Guidelines. }{ }^{16}\end{array}$ \\
\hline OSSA & Not indicated. \\
\hline IRSO & No COVID-19 information available. \\
\hline $\mathrm{CHOS}$ & No COVID-19 information available. \\
\hline
\end{tabular}

RCOphth: The Royal College of Ophthalmologists (https://www. rcophth.ac.uk/).

AAO: American Academy of Ophthalmology (https://www.aao. org/).

COS: Canadian Ophthalmological Society (https://www.cosprc. $\mathrm{ca} /$ ).

SEO: Sociedad Española de Oftalmología/Spanish Society of Ophthalmology (https://www.oftalmoseo.com/).

SFO: Société Française d'Ophthalmologie/French Society of Ophthalmology (https://www.sfo-online.fr/).

DOG: Deutsche Ophthalmologische Gesselschaft/German Ophthalmological Society (https://www.dog.org/).

SOI: Società Oftalmologica Italiana/Italian Ophthalmological Society (https://www.sedesoi.com/).

JOS: Japanese Ophthalmological Society (http://www.nichigan. or.jp/).

AIOS: All India Ophthalmological Society (https://aios.org/). OSSA: Ophthalmological Society of South Africa (https://www. ossa.co.za/).

IRSO: Iranian Society of Ophthalmology (http://www.irso.org/). CHOS: Chinese Ophthalmological Society (https://www.apaophth. org/chinese-ophthalmological-society/ and http://www.cma.org. $\mathrm{cn} /$ ). and delaying anti-VEGF treatment for retinal vein occlusion. ${ }^{36}$ However, SFO mentions that injections should be kept for neovascular AMD and other neovascular diseases associated with high myopia and inflammatory pathologies. $^{21} 37$

\section{Uveitis}

The UK provides specific guidance for uveitis: although most in-person consultations must be deferred, some patients must require a review within 4 months. ${ }^{25}$ 38-40 SFO has published a document detailing the approach when caring for patients with uveitis during the pandemic (mandatory use of gloves and use of angiography and OCT only when deemed essential). ${ }^{41}$

\section{Glaucoma}

RCOphth and SFO have established management plans for patients with glaucoma. RCOphth provides a comprehensive document detailing steps that physicians must undergo to best manage their patients. This management plan takes into account risk associated with vision loss (due to patients staying at home and not receiving appropriate care), population spread instead of physical distancing (due to in-person visits) and mortality resulting from medical setting acquired COVID-19 (due to care provided in-person). ${ }^{42}$ SFO specifically recommends applanation over air tonometry as the latter could spread infectious particles. ${ }^{43}$

\section{Paediatrics}

These two societies give guidelines for paediatric patient management. ${ }^{17} 44 \mathrm{SFO}$ indicates that all children suspected of having strabismus or leukocoria be brought to an emergency room or clinic for dilated fundus photography.

\section{Care for patients with COVID-19 ocular symptoms}

RCOphth mentions recent reports that conjunctivitis could be caused by COVID-19 but states that it is unlikely that a person with viral conjunctivitis and no other COVID-19 symptom (ie, fever or cough) would have COVID-19 because conjunctivitis may be a late characteristic of the virus. ${ }^{45}$

AAO has reported that mild follicular conjunctivitis can occur in patients with COVID-19 and that transmission might be by aerosol contact with the conjunctiva. Conjunctivitis symptoms are not necessarily due to COVID-19, as it can be due to alternate viral aetiologies. ${ }^{46}{ }^{47}$ As mentioned by JOS on 1 April, the risk of contracting COVID-19 via the conjunctiva is about $1 \%-3 \%$, but this number may fluctuate as more studies are conducted. ${ }^{48}$

SFO and JOS have warned about the potential association between red eyes and conjunctivitis. AIOS recommends that patients with conjunctivitis should wait in an isolated waiting room before being seen by an ophthalmologist in full PPE in a designated room. ${ }^{19}$ 
Recommendations on hygiene, PPE and safety for ophthalmic use

In the context of the pandemic, all 10 societies with COVID-19 information on their website released statements regarding PPE and responsible resource stewardship. They all highlight the importance of hand hygiene. Many societies, like SEO, DOG and JOS, refer their members to the WHO's website, which emphasises five moments for hand hygiene (1: before touching the patient, 2: before clean/aseptic procedures, 3: after body fluid exposure risk, 4: after touching a patient and 5: after touching patient surroundings). ${ }^{49}$ All 10 societies recommend their members to proceed to thorough surface disinfections after every patient. DOG and SOI even remind members to pay particular attention to door handles (table 4).

AAO highlights the controversy regarding what qualifies as adequate PPE for ophthalmologists, in the context of the PPE shortages around the world and the efficacy of masks. Guidelines differ from one hospital to another across the USA, varying from prohibition to mandatory use of masks. In stark contrast to COS, SFO, SOI, DOG, JOS and RCOphth, AAO does not emit its own recommendations regarding PPE use and refers its members to the CDC's website. ${ }^{46}$

Apart from AAO, the nine other societies have provided recommendations on the use of slit-lamp shields, single-use gloves, masks, face shields, goggles, gowns and even on shoe protectors. The level of detail associated with each recommendation is variable.

For example, RCOphth established a list of specific scenarios accompanied with appropriate PPE use and even mentions if PPE can be used for an entire session or is single use. ${ }^{50}$ RCOphth's PPE advice and principles are based on Public Health England recommendations. ${ }^{5253}$

COS specifies the use of large slit-lamp shields to protect ophthalmologist from patient breathing, coughing and sneezing. The Canadian society further refers its members to three videos on how to make slitlamp and microscope shields and advertises free slit lamp breath shields. ${ }^{32}$ Other videos included videos on its website include some on how to don and doff PPE during routine care of all suspected patients with COVID-19. ${ }^{54}$

Similarly to RCOphth, SFO established clear guidelines and provided concrete examples for different PPE use. For instance, physicians caring for a suspected patients with COVID-19 must wear a FFP2 mask, while those caring for confirmed patients with COVID-19 must wear FFP2 mask in addition to gloves, a supplementary gown, hair cover and protection glasses. ${ }^{556}$

A few additional variants exist between different countries, such as for the recommended safety distance between two people, SEO, SFO and AIOS recommend a minimum distance of $1 \mathrm{~m}$ between patients, while DOG recommends $2 \mathrm{~m}$.
Other recommendations

$\mathrm{AAO}$ and COS included advice on stress management, health and wellness. These two societies and AIOS provide resources on financial wellness to their members. The use of hydroxychloroquine is discussed by SFO and SEO. Contact lenses recommendations are provided by SFO, SOI and SEO.

\section{DISCUSSION}

Ten out of the 12 societies examined created operational guidelines for ophthalmic practice during the outbreak. Only IRSO and the CHOS have not provided recommendations on patient care during the COVID-19 pandemic.

All the other societies have displayed recommendations to their members through different formats on the ophthalmology societies' websites (ie, videos, articles, notices, resource list and task force reports) and have recommended that ophthalmologists only take care of urgent cases. All 10 ophthalmology societies with COVID-19 information on their respective website have emphasised the following core principle: non-urgent medical and surgical care must be limited. Care must only be provided to urgent cases, and elective surgeries must be cancelled or postponed, in order to minimise the risk of spreading infection. These societies urge physicians to consider the potential transmission risks and the patients' well-being, especially in the context of ophthalmic patients who are elderly and considered high risk. ${ }^{1720}$ The consensus is that ophthalmic care is deemed urgent if a patient risks irreversible vision loss if not treated in a timely fashion or managed appropriately. In contrast, non-urgent care can typically be postponed for several weeks to months without risking blindness. Guidelines surrounding urgent care slightly vary between countries, as RCOphth, AAO and SFO have published their own guidelines. For instance, SFO has added a semiurgent category in order to help ophthalmologists distinguish high priority eye emergencies from other urgent procedures that can be postponed with cautious management.

While each society recommends urgent versus elective care, a large portion of which can be provided from the ophthalmologists' home (telehealth consultations), only a few societies (RCOphth, AAO and AIOS) provide detailed telehealth resources for ophthalmologists.

Recommendations for procedures related to different ophthalmology subspecialties (ie, cornea, glaucoma, neuro-ophthalmology, ocular oncology, oculoplastics, paediatrics and retina) were directly provided by certain societies, namely SFO, or were found statements written by national ophthalmological subspecialty societies (eg, COS refers its members to the Canadian Retina Society for the management of retinal diseases).

Some societies have warned ophthalmologists that conjunctivitis may be a COVID-19 symptom and that COVID-19 transmission via the conjunctiva might be plausible. As ophthalmologists' duty to provide care to patients may include COVID-19 infected patients who 
Table 4 Summary of hygiene, PPE and safety recommendations for ophthalmologists during the COVID-19 pandemic per international ophthalmology society

\section{Recommendations on}

\begin{tabular}{|c|c|c|c|c|c|c|}
\hline Society & $\begin{array}{l}\text { Hand hygiene } \\
\text { and } \\
\text { surface } \\
\text { disinfection }\end{array}$ & $\begin{array}{l}\text { Slit-lamp } \\
\text { shields }\end{array}$ & $\begin{array}{l}\text { Single-use } \\
\text { gloves }\end{array}$ & Masks & Other & $\begin{array}{l}\text { Safety distance between } \\
\text { patients }\end{array}$ \\
\hline RCOphth & Yes & Yes & Yes & $\begin{array}{l}\text { Fluid-resistant type } \\
\text { IIR surgical mask. }\end{array}$ & $\begin{array}{l}\text { Filtering face } \\
\text { piece respirator. } \\
\text { Eye or face } \\
\text { protection. } \\
\text { Disposable } \\
\text { plastic apron. } \\
\text { Disposable } \\
\text { fluid-resistant } \\
\text { gown. }\end{array}$ & NA \\
\hline
\end{tabular}

AAO Yes $\quad$ Referral to the CDC: Standard Precautions page, where hand hygiene, cough etiquette, PPE use and surface disinfection are described. AAO notes that the use of PPE varies from one institution to another and must be dealt on a case-by-case basis, as there are worldwide shortages of PPE.

\begin{tabular}{|c|c|c|c|c|c|c|}
\hline $\cos$ & Yes & Yes & Yes & $\begin{array}{l}\text { 1. Fitted N95 (best } \\
\text { prevention). } \\
\text { 2. Surgical mask } \\
\text { (if N95 not } \\
\text { available and for } \\
\text { routine care). }\end{array}$ & $\begin{array}{l}\text { Face shield. } \\
\text { Goggles or } \\
\text { other eye } \\
\text { protection. } \\
\text { Single-use } \\
\text { applanation tips } \\
\text { and drops. }\end{array}$ & NA \\
\hline SEO & Yes & Yes & Yes & $\begin{array}{l}\text { FFP2 (N95) or } \\
\text { FFP3 masks. }\end{array}$ & $\begin{array}{l}\text { Protective } \\
\text { eyewear. } \\
\text { Pinholes use } \\
\text { discouraged. }\end{array}$ & $1 \mathrm{~m}$ \\
\hline SFO & Yes & Not indicated & Yes & $\begin{array}{l}\text { 1. FFP2 mask. } \\
\text { 2. Surgical mask (if } \\
\text { FFP2 mask not } \\
\text { available). }\end{array}$ & $\begin{array}{l}\text { Goggles. } \\
\text { Surgical gown } \\
\text { or plastic apron. } \\
\text { Shoe } \\
\text { protectors. }\end{array}$ & $1 \mathrm{~m}$ \\
\hline DOG & Yes & Not indicated & Yes & $\begin{array}{l}\text { 1. Respiratory } \\
\text { mask. } \\
\text { 2. Surgical mask } \\
\text { (if respiratory } \\
\text { mask not } \\
\text { available). }\end{array}$ & NA & $2 \mathrm{~m}$ \\
\hline SOI & Yes & Not indicated & Yes & $\begin{array}{l}\text { 1. FFP2 mask. } \\
\text { 2. Surgical mask (if } \\
\text { FFP2 mask not } \\
\text { available). }\end{array}$ & Goggles. & NA \\
\hline JOS & Yes & Not indicated & Yes & Recommended. & $\begin{array}{l}\text { Face shield. } \\
\text { Goggles or } \\
\text { other eye } \\
\text { protection. } \\
\text { Apron. } \\
\text { Caps. } \\
\text { Gowns. } \\
\text { Shoe covers. }\end{array}$ & NA \\
\hline AlOS & Yes & Yes & Yes & $\begin{array}{l}\text { Triple layered/N95 } \\
\text { masks if available. }\end{array}$ & $\begin{array}{l}\text { Goggles or face } \\
\text { shields. } \\
\text { Disposable } \\
\text { gowns. }\end{array}$ & $1 \mathrm{~m}$ \\
\hline
\end{tabular}




\begin{tabular}{|c|c|c|c|c|c|c|}
\hline Society & $\begin{array}{l}\text { Hand hygiene } \\
\text { and } \\
\text { surface } \\
\text { disinfection }\end{array}$ & $\begin{array}{l}\text { Slit-lamp } \\
\text { shields }\end{array}$ & $\begin{array}{l}\text { Single-use } \\
\text { gloves }\end{array}$ & Masks & Other & $\begin{array}{l}\text { Safety distance between } \\
\text { patients }\end{array}$ \\
\hline OSSA & Yes & Not indicated & Yes & Face masks. & Aprons. & NA \\
\hline IRSO & \multicolumn{6}{|c|}{ No COVID-19 information available. } \\
\hline CHOS & \multicolumn{6}{|c|}{ No COVID-19 information available. } \\
\hline
\end{tabular}

RCOphth: The Royal College of Ophthalmologists (https://www.rcophth.ac.uk/).

AAO: American Academy of Ophthalmology (https://www.aao.org/).

COS: Canadian Ophthalmological Society (https://www.cosprc.ca/).

SEO: Sociedad Española de Oftalmología/Spanish Society of Ophthalmology (https://www.oftalmoseo.com/).

SFO: Société Française d'Ophthalmologie/French Society of Ophthalmology (https://www.sfo-online.fr/).

DOG: Deutsche Ophthalmologische Gesselschaft/German Ophthalmological Society (https://www.dog.org/).

SOI: Società Oftalmologica Italiana/Italian Ophthalmological Society(https://www.sedesoi.com/)

JOS: Japanese Ophthalmological Society (http://www.nichigan.or.jp/).

AIOS: All India Ophthalmological Society (https://aios.org/).

OSSA: Ophthalmological Society of South Africa (https://www.ossa.co.za/).

IRSO: Iranian Society of Ophthalmology (http://www.irso.org/).

CHOS: Chinese Ophthalmological Society (https://www.apaophth.org/chinese-ophthalmological-society/ and http://www.cma.org.cn/).

$\mathrm{PPE}$, personal protective equipment.

require urgent care, protocols, hygiene measures and PPE for ophthalmology in-person consultations have been established by the ten societies with COVID-19 recommendations.

\section{Conclusion}

Eye care providers worldwide are facing unprecedented challenges in caring for patients. In the context of a global pandemic, decisions must be made in respect to priority setting. In hospitals and outpatient clinics, patients are inevitably being triaged to first manage the most critically ill and those with the best chances of survival. All major ophthalmology societies from the G7 countries in addition to SEO, AIOS and OSSA have provided valuable information concerning COVID-19 for members on their websites. Some of them have referred their members to other resources, such as COS, DOG and JOS that have redirect their members to AAO reports. While there is no clear consensus on ophthalmology guidelines across the world (especially on PPE use), this paper provides ophthalmologists and all eye care providers a complete overview of international guidelines for ophthalmic care during the COVID-19 pandemic and invites them to apply best practices based on these recommendations.

Contributors All authors have: substantial contributed to the conception of the work (the acquisition, analysis and interpretation of data for the work); drafted and revised the work; approved the final version to be published; and agreed to be accountable for all aspects of the work in ensuring that questions related to the accuracy and integrity of any part of the work are appropriately investigated and resolved.

Funding The authors have not declared a specific grant for this research from any funding agency in the public, commercial or not-for-profit sectors.

Competing interests None declared.

Patient consent for publication Not required.

Provenance and peer review Not commissioned; externally peer reviewed.
Data availability statement Data are available upon request.

Open access This is an open access article distributed in accordance with the Creative Commons Attribution Non Commercial (CC BY-NC 4.0) license, which permits others to distribute, remix, adapt, build upon this work non-commercially, and license their derivative works on different terms, provided the original work is properly cited, appropriate credit is given, any changes made indicated, and the use is non-commercial. See: http://creativecommons.org/licenses/by-nc/4.0/.

\section{ORCID iDs}

Anne X Nguyen http://orcid.org/0000-0002-3999-946X

Kalla A Gervasio http://orcid.org/0000-0003-4277-7347

Albert Y Wu http://orcid.org/0000-0002-1360-8248

\section{REFERENCES}

1 World Health Organization. Coronavirus disease: situation report-112. Available: https://www.who.int/docs/default-source/ coronaviruse/situation-reports/20200511-covid-19-sitrep-112.pdf? sfvrsn=813f2669_2 [Accessed 11 May 2020].

2 Davidson H. First Covid-19 case happened in november, China government records show - report, 2020. Available: https://www. theguardian.com/world/2020/mar/13/first-covid-19-case-happenedin-november-china-government-records-show-report [Accessed 11 May 2020].

3 World Health Organization. Modes of transmission of virus causing COVID-19: implications for IPC precaution recommendations, 2020. Available: https://www.who.int/news-room/commentaries/detail/ modes-of-transmission-of-virus-causing-covid-19-implications-foripc-precaution-recommendations [Accessed 11 May 2020].

4 Seah IYJ, Anderson DE, Kang AEZ, et al. Assessing viral shedding and infectivity of tears in coronavirus disease 2019 (COVID-19) patients. Ophthalmology 2020;127:977-9.

5 Xia J, Tong J, Liu M, et al. Evaluation of coronavirus in tears and conjunctival secretions of patients with SARS-CoV-2 infection. $J$ Med Virol 2020;92:589-94.

6 The Royal College of Ophthalmologists. The Royal college of ophthalmologists, 2020. Available: https://www.rcophth.ac.uk/ [Accessed 11 May 2020].

7 American Academy of Ophthalmology. American academy of ophthalmology, 2020. Available: https://www.aao.org/ [Accessed 11 May 2020].

8 Canadian Ophthalmological Society - Eye Physicians and Surgeons of Canada. Canadian ophthalmological society - eye physicians and surgeons of Canada, 2020. Available: https://www.cos-sco.ca/ [Accessed 11 May 2020]. 
9 Sociedad Española de Oftalmología. Recomendaciones para La atención a pacientes oftalmológicos en relación con emergencia COVID-1, 2020. Available: https://www.oftalmoseo.com/ documentacion/comunicado_conjunto_oftalmologia_covid19v2.pdf [Accessed 11 May 2020].

10 Gesellschaft Deutsche Ophthalmologische. Informationen zum thema COVID-19 finden Sie, 2020. Available: https://www.dog.org/ [Accessed 11 May 2020].

11 Italiana Societ Oftalmologica. Portale degli Oculisti Italiani, 2020. Available: https://www.sedesoi.com/index.php [Accessed 11 May 2020].

12 The Japanese Ophthalmological Society. Notice list, 2020 Available: http://www.nichigan.or.jp/index.jsp [Accessed 11 May 2020].

13 All India Ophthalmological Society. All India ophthalmological society - from darkness to light, 2020. Available: https://aios.org/ [Accessed 11 May 2020].

14 Ophthalmological Society of South Africa. Welcome to OSSA, 2020. Available: https://www.ossa.co.za/ [Accessed 11 May 2020].

15 Chinese Ophthalmological Society. Chinese ophthalmological society, 2020. Available: https://www.apaophth.org/chineseophthalmological-society/ [Accessed 11 May 2020].

16 Iranian Society of Ophthalmology. Secondary Iranian society of ophthalmology website, 2020. Available: http://www.irso.org/ [Accessed 11 May 2020].

17 The Royal College of Ophthalmologists. COVID-19 clinical guidance for ophthalmologists, 2020. Available: https://rcophth.ac.uk/2020/ 04/covid-19-update-and-resources-for-ophthalmologists/ [Accessed 11 May 2020].

18 American Academy of Ophthalmology. New recommendations for urgent and nonurgent patient care, 2020. Available: https://www.aao. org/headline/new-recommendations-urgent-nonurgent-patient-care [Accessed 11 May 2020].

19 All India Ophthalmological Society. AIOS operational guidelines for ophthalmic practice during COVID 19 outbreak, 2020. Available: https://aios.org/pdf/AIOS-Operational-Guidelines-COVID19.pdf [Accessed 11 May 2020].

20 Deutsche Ophthalmologische Gesselschaft. Coronavirus COVID-19, 2020. Available: https://www.dog.org/?cat=288 [Accessed 11 May 2020].

21 La Société Française d'Ophthalmologie. Quelle conduite tenir pour la prise en charge de pathologies chirurgicales vitréo-rétiniennes en cette période d'épidémie de Covid-19 virus SARS-CoV-2 ? 2020. Available: https://www.sfo-online.fr/actualites/quelle-conduitetenir-pour-la-prise-en-charge-de-pathologies-chirurgicales-vitreo [Accessed 11 May 2020].

22 Italiana Societ Oftalmologica. Emergenza Coronavirus: prestazioni medico oculistiche, manuale d'Uso, video messaggio del presidente, 2020. Available: https://www.sedesoi.com/leggi_news.php?id=1886 [Accessed 11 May 2020].

23 Ophthalmological Society of South Africa. COVID-19 information for the opthalmology patient, 2020. Available: https://ossa.autoprax.co. za/api/images/pdf/5e788b26b09791041d2e7d8f [Accessed 11 May 2020].

24 The Royal College of Ophthalmologists. Telemedicine applications for ophthalmology consultations during a pandemic emergency, 2020. Available: https://www.rcophth.ac.uk/wp-content/uploads/ 2020/03/Telemedicine-Options-for-Ophthalmology-ConsultationsCOVID19.pdf [Accessed 11 May 2020].

25 The Royal College of Ophthalmologists. Medical retinal management plans during COVID-19, 2020. Available: https://www.rcophth.ac.uk/ wp-content/uploads/2020/03/Medical-Retinal-Management-Planduring-COVID-19-UPDATED-300320-1-3.pdf [Accessed 11 May 2020].

26 American Academy of Ophthalmology. Telehealth resources, 2020. Available: https://www.aao.org/practice-management/telehealth [Accessed 11 May 2020].

27 American Academy of Ophthalmology. Coronavirus impact: telemedicine considerations, 2020. Available: https://www.aao.org/ practice-management/article/coronavirus-telemedicine-telehealthconsiderations [Accessed 11 May 2020]

28 American Academy of Ophthalmology. Teleophthalmology: how to get started, 2020. Available: https://www. aao.org/practicemanagement/article/teleophthalmology-how-to-get-started [Accessed 11 May 2020].

29 American Academy of Ophthalmology. Coding for phone calls, Internet and telehealth consultations, 2020. Available: https://www. aao.org/practice-management/news-detail/coding-phone-callsinternet-telehealth-consult [Accessed 11 May 2020].

30 American Academy of Ophthalmology. Coronavirus impact: teleworking considerations, 2020. Available: https://www.aao.org/ practice-management/article/coronavirus-telework-remote-practiceoperations [Accessed 11 May 2020].

31 American Academy of Ophthalmology. Academy, federal agencies issue new telehealth guidance in light of COVID-19, 2020.

Available: https://www.aao.org/eye-on-advocacy-article/academyfederal-agencies-issue-telehealth-guidance [Accessed 11 May 2020].

32 Canadian Ophthalmological Society and Association of Canadian University Professors of Ophthalmology. COS and ACUPO guidelines for ophthalmic care during COVID-19 pandemic, 2020. Available: https://www.cosprc.ca/resource/guidelines-forophthalmic-care/ [Accessed 11 May 2020].

33 The Royal College of Ophthalmologists. Vitreoretinal surgery during the COVID-19 pandemic, 2020. Available: https://www.rcophth.ac. uk/wp-content/uploads/2020/04/Vitreoretinal-surgery-managementguidance-070420.pdf [Accessed 11 May 2020].

34 American Academy of Ophthalmology. Coronavirus and eye care, 2020. Available: https://www.aao.org/coronavirus [Accessed 11 May 2020]

35 American Society of Retina Specialists. COVID-19: updates and resources, 2020. Available: https://www.asrs.org/practice/asrsmember-alert-regarding-covid-19-pandemic [Accessed 11 May 2020].

36 Canadian Ophthalmological Society. Additional considerations to help manage the anti-VEGF injection burden during the COVID-19 pandemic, 2020. Available: https://www.cosprc.ca/resource/ additional-considerations-to-help-manage-the-anti-vegf-injectionburden-during-the-covid-19-pandemic/ [Accessed 11 May 2020]

37 La Société Française d'Ophthalmologie. IVT - Épidémie au COVID-19, 2020. Available: https://www.sfo-online.fr/actualites/ivtepidemie-au-covid-19 [Accessed 11 May 2020].

38 Uveitis National Study Group. Guidance on COVID-19, 2020. Available: https://www.uveitisstudygroup.org/ [Accessed 11 May 2020]

39 CCAA. Coronavirus support \& ressources, 2020. Available: https:// www.ccaa.org.uk/coronavirus-support-resources/ [Accessed 11 May 2020].

40 British Society for Rheumatology. COVID-19: guidance for rheumatologists, 2020. Available: https://www.rheumatology.org uk/news-policy/details/covid19-coronavirus-update-members [Accessed 11 May 2020].

41 La Société Française d'Ophtalmologie. Conduite tenir pour le suivi des patients atteints d'uvéite au cours de la pandémie Covid-19, 2020. Available: https://www.sfo-online.fr/actualites/conduitetenir-pour-le-suivi-des-patients-atteints-duveite-au-cours-de-lapandemie-covid [Accessed 11 May 2020].

42 RCOphth COVID-19 Review Team. Glaucoma management plans during COVID-19, 2020. Available: https://www.rcophth.ac.uk/wpcontent/uploads/2020/03/Glaucoma-Service-Management-Plansduring-COVID-19-270320.pdf [Accessed 11 May 2020].

43 La Société Française d'Ophtalmologie. Quelle conduite tenir pour le suivi des patients glaucomateux - Épidémie au Covid-19, 2020 Available: https://www.sfo-online.fr/actualites/quelle-conduite-tenirpour-le-suivi-des-patients-glaucomateux-epidemie-au-covid-19 [Accessed 11 May 2020].

44 La Société Française d'Ophtalmologie. Consultations d'ophtalmopédiatrie - épidémie Covid-19, 2020. Available: https:// www.sfo-online.fr/actualites/consultations-dophtalmopediatrieepidemie-covid-19 [Accessed 11 May 2020].

45 The Royal College of Ophthalmologists and the College of Optometrists.. Viral conjunctivitis and COVID-19 joint statement, 2020. Available: https://www.rcophth.ac.uk/2020/03/viralconjunctivitis-and-covid-19-a-joint-statement-from-the-royalcollege-of-ophthalmologists-and-college-of-optometrists/ [Accessed 11 May 2020].

46 American Academy of Ophthalmology. Important coronavirus updates for ophthalmologists, 2020. Available: https://www.aao. org/headline/alert-important-coronavirus-context [Accessed 11 May 2020]

47 Today. Pink eye may be a rare symptom of coronavirus, doctors say, 2020. Available: https://www.today.com/health/coronavirussymptoms-pink-eye-viral-conjunctivitis-may-be-rare-warningt176792 [Accessed 11 May 2020].

48 The Japanese Opthalmological Society. Information about eyes of new coronavirus infectious disease (to citizens), 2020. Available: http://www.nichigan.or.jp/news/068.jsp [Accessed 11 May 2020]

49 World Health Organization. Hand hygiene: why how \& when? 2009 Available: https://www.who.int/gpsc/5may/Hand_Hygiene_Why_ How_and_When_Brochure.pdf [Accessed 11 May 2020]

50 The Royal College of Ophthalmologists. PPE and staff protection requirements for ophthalmology, 2020. Available: https://www. 
rcophth.ac.uk/wp-content/uploads/2020/04/UPDATED-RCOphthPPE-for-ophthalmology-090420.pdf [Accessed 11 May 2020].

51 The Royal College of Ophthalmologists. PPE and staff protection requirements for ROP screening and treatment, 2020. Available: https://www.rcophth.ac.uk/wp-content/uploads/2020/04/NEW$\mathrm{PPE}$-and-staff-protection-requirements-for-ROP-screening-andtreatment-090420.pdf [Accessed 11 May 2020]

52 The Royal College of Ophthalmologists. PPE requirements for ophthalmology, 2020. Available: https://www.rcophth.ac.uk/wpcontent/uploads/2020/04/UPDATED-RCOphth-PPE-Principles-forophthalmic-staff-protection-090420.pdf [Accessed 11 May 2020].

53 Public Health England. Coronavirus (COVID-19): what you need to do, 2020. Available: https://www.gov.uk/government/organisations/ public-health-england [Accessed 11 May 2020].
54 Canadian Ophthalmological Society. Videos for donning \& doffing PPE, 2020. Available: https://www.cosprc.ca/resource/videos-fordonning-doffing-ppe/ [Accessed 11 May 2020].

55 La Société Française d'Ophthalmologie. Les urgences neuroophtalmologiques pendant l'infection COVID19, 2020. Available: https://www.sfo-online.fr/actualites/les-urgences-neuroophtalmologiques-pendant-linfection-covid19 [Accessed 11 May 2020].

56 La Société Française d'Ophthalmologie and L'Académie Française d'Ophthalmologie. Recommandations COVID pour les ophtalmologistes - 15 Mars, 2020. Available: https://www.sfo-online. fr/sites/www.sfo-online.fr/files/medias/documents/recos_covid_afo_ 15_mars_version_longue.pdf [Accessed 11 May 2020]. 